\title{
Terceirização: \\ a derruição de direitos e a destruição da saúde dos trabalhadores*
}

\section{Outsourcing: the dilapidation of rights and the damage to the laborers' health}

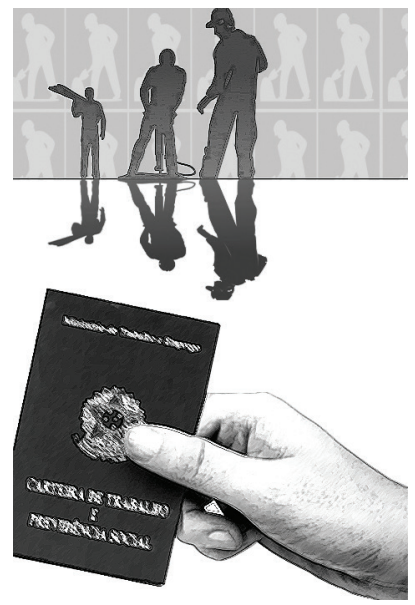

\author{
Edvânia Ângela de Souza Lourenço** \\ Assistente social e professora doutora do Departamento de Serviço \\ Social da Faculdade de Ciências Humanas e Sociais de Franca (FCHS), \\ Unesp, Franca/SP, Brasil.
}

Resumo: Este texto discute as relações sociais de trabalho contemporâneas e suas determinações para os agravos à saúde dos trabalhadores, os quais, na maioria das vezes, são ocultados. Trata-se de compreender a ameaça aos direitos trabalhistas e previdenciários, como propõe a terceirização do trabalho e da produção, com impactos à saúde dos trabalhadores. Por fim, espera-se contribuir com o desvendamento do real significado da terceirização para o trabalho e respectivos direitos. Espera-se também contribuir com o campo da saúde do trabalhador, bem como com o trabalho profissional do Serviço Social neste campo.

Palavras-chave: Terceirização. Agravos à saúde do trabalhador. Notificação dos acidentes e doenças relacionadas ao trabalho. Usinas de açúcar e álcool.

\begin{abstract}
This article is about the social relationships of the contemporary labor and their determination to the harm to the laborers' health. This latter fact is usually concealed. It is about understanding how labor and social security law is threatened, as it is proposed by the outsourcing of labor and production, with impact on the laborers' health. Finally, we hope to contribute to the unveiling of the real meaning of the outsourcing of labor and its respective rights.
\end{abstract}

Keywords: Outsourcing. Harm to the laborers' health. Notification of accidents and illnesses related to work. Sugar and alcohol mills.

* Registra-se um agradecimento especial à professora doutora Raquel Raichelis pela importante contribuição ao debate realizado neste texto.

**E-mail: edvaniaangela@hotmail.com. 


\section{À guisa de introdução}

$\mathbf{P}$ arece até uma incoerência falar em saúde do trabalhador ${ }^{1}$ num momento de tamanha derruição dos direitos sociais no Brasil. Deste modo, antes de qualquer argumento é preciso saber que saúde se garante com melhores condições de vida e de trabalho. Sem isso, o discurso da saúde do trabalhador cai no vazio ou na austeridade de regras que imputam às vítimas do trabalho a culpa pela deterioração da sua saúde.

Pensar a saúde do trabalhador exige um esforço intelectual e político para compreender as relações sociais de trabalho, bem como a especificidade do processo e da organização e gestão do trabalho na atual conjuntura. Saúde do trabalhador é uma condição muito particular que reflete o modo como as tarefas são desempenhadas, as habilidades exigidas, as condições ambientais e tecnológicas que envolvem o processo de trabalho, a administração/gestão e organização do trabalho, mas, sobretudo, o vaticínio do reforço da condição de classe por efeito da divisão social do trabalho e, consequentemente, relações salariais, jornada de trabalho e subordinação voluntária às imposições do mercado. Saúde do trabalhador é o verdadeiro tecido conjuntivo das relações sociais de trabalho, que põe a nu a condição de exploração e as contradições reais existentes entre as classes.

Portanto, a discussão ora proposta - "terceirização: a derruição de direitos e a destruição da saúde (física e mental) dos trabalhadores" — tem como eixo ordenador o entendimento da saúde do trabalhador para muito além dos eventos que homens e mulheres sofrem no seu ambiente de trabalho ou em razão dele. Apesar de os dados estatísticos dos agravos à saúde dos trabalhadores ${ }^{2}$ fornecerem indicativos importantes das relações sociais de trabalho, compreendendo o modo como o trabalho é executado (fragmentado, parcelado e a mecanização das atividades laborais) e como está organizado e gerido, é preciso considerar a realização do ser no e pelo trabalho. Não é de surpreender que o nível de sofrimento que assombra os trabalhadores, nem sempre convertido em patologias, resulta em problemas que atingem a esfera mental e advém do modo como o trabalho está organizado, bem como das atuais mudanças operacionais e da gestão do trabalho, advém também

1. Neste texto, o uso da palavra trabalhador, no masculino, considera o ser social — gênero humano, seja homem ou mulher.

2. Agravos à saúde dos trabalhadores compreendem os eventos que agridem a saúde, podendo ser acidentes ou doenças relacionadas ao trabalho. 
dos impactos causados pela miséria do desemprego, da divisão social do trabalho e de classes.

Entender a saúde do trabalhador exige conhecer os índices de afastamento devido às várias morbidades, acidentes e mortes provocadas pelo ou no trabalho. Contudo, é preciso ir além e compreender as relações sociais de trabalho. É importante ressaltar que os dados de agravos à saúde dos trabalhadores no Brasil não coincidem com a realidade em que os trabalhadores estão inseridos, ou seja, os dados são subnotificados e não compreendem a totalidade dos trabalhadores.

Vale referir aqui o peso que as novas medidas de austeridade fiscal, acompanhadas da nova lei em tramitação no Congresso Nacional, de n. $4.330,{ }^{3}$ terão para o trabalho e a saúde dos trabalhadores. As Medidas Provisórias ns. 664 e 665, ${ }^{4}$ acompanhadas da lei, que permite a terceirização em todas as fases da atividade empresarial, representam os esforços do capital para atingir a maximização da produtividade do trabalho sem efetivar investimentos nas inovações tecnológicas e de infraestrutura dos empreendimentos.

Um dos primeiros aspectos a ser ressaltado é que essas medidas compõem as estratégias de enfrentamento à crise do capital, a qual é oriunda de um longo processo histórico, cujas dimensões de aprofundamento ocorreram em 2007-08. Contudo, a crise vem sendo disseminada, sobretudo pela mídia, como crise do "governo petista", num momento de esgotamento da tentativa deste governo favorecer o mercado interno por meio de políticas de transferências de renda e aumento do salário mínimo real e da formalização do trabalho, como feito nos dez anos do governo do PT, o que implicou o denominado neodesenvolvimentismo (Alves, 2014).

As mudanças ora propostas, que restringem os direitos trabalhistas e previdenciários, expressam o rompimento do ciclo civilizacional proposto pelo capitalismo a partir das lutas entre capital e trabalho, significam, entre outros, os limites do projeto civilizacional burguês. É a derruição dos limites outrora impostos à

3. A classe empresarial brasileira obteve no início deste ano (2015) grande vitória sobre o trabalho. O Congresso Nacional aprovou o Projeto de lei n. 4.330, de autoria de Sandro Mabel (PMDB), empresário do ramo alimentício, dono da fábrica de biscoitos Mabel. O PL n. 4.330 permite a ampla terceirização do trabalho e de trabalhadores no país. Até o momento, a terceirização era permitida apenas para a atividade-meio da empresa. Com a nova lei, a atividade principal (ou atividade-fim) também pode ser terceirizada.

4. Após intensa disputa eleitoral para a presidência da República, Dilma Rouseff, do Partido dos Trabalhadores (PT), foi reeleita, mas antes mesmo de iniciar o seu novo mandato, ainda no final de 2014, anunciou um conjunto de medidas que restringem o acesso ao seguro-desemprego, auxílio-doença, abono salarial e a pensão por morte. 
extração da mais-valia absoluta. A terceirização remete ao ciclo inicial da industrialização capitalista, combina elementos de más condições de trabalho, baixos salários e aumento da jornada. Portanto, tem consequências arrasadoras sobre o trabalho e as representações sindicais.

O sistema capitalista é marcado pelas suas fases de expansão e de estagnação. Chesnais (2008) aborda as crises da economia capitalista como um processo. Portanto, a crise que ocorreu em 1929 compõe-se de um processo histórico mais amplo. Desta forma, a crise de 2007, localizada nos mercados financeiros, em especial nas Bolsas de Valores dos grandes centros financeiros, deve ser vista como parte do mesmo processo histórico do sistema capitalista. Citando Marx, Chesnais afirma que as crises representam os limites históricos da produção capitalista, cujo objetivo é a sua própria valorização, e não a ampliação estrutural das sociedades e respectivas condições de vida.

De aquí que los límites dentro de los cuales tiene que moverse la conservación y valorización del valor-capital, la cual descansa en la expropiación y depauperación de las grandes masas de los productores, choquen constantemente con los métodos de producción que el capital se ve obligado a emplear para conseguir sus fines y que tienden al aumento ilimitado de la producción, a la producción por la producción misma, al desarrollo incondicional de las fuerzas sociales productivas del trabajo... (Marx, 1973, p. 248, apud Chesnais, 2008)

Esta análise permite visualizar a dialética do sistema de produção capitalista, o qual é capaz de criar e desenvolver um mercado mundial. Contudo, sua fórmula voltada exclusivamente para a valorização do capital se choca constantemente com as condições de reprodução da vida e de trabalho.

A crise do sistema capitalista fundamentada nos dias atuais pelo Estado neoliberal e estruturada pela busca irrefreável de acumulação aparece convertida nas crises isoladas, como crise da "Bolsa", "hipotecária", "subprimes", conforme analisado por Chesnais (2008), que chama a atenção também para a crise hídrica que a médio prazo poderá desencadear a luta de classes pelo acesso a água.

Para Chesnais (2008), a compreensão da crise atual exige o reconhecimento do processo histórico do capital, o qual, na busca de superar os limites de acumulação e suas crises, ${ }^{5}$ cria novos limites. O autor fundamenta três formas de superação

5. O capital fictício na forma de crédito que visava romper com os limites de acumulação criou outros. Como mostrado por Chesnais, os créditos hipotecários já indicavam a sua vulnerabilidade e fragilidade 
dos limites do capitalismo que recorreram a outros mais agudos ainda: 1) a liberalização financeira, do comércio e da inversão, e a destruição das garantias de direitos surgidas no contexto pós-Segunda Guerra Mundial; 2) a criação do capital fictício e dos meios de crédito para ampliar as demandas do centro do sistema; 3 ) a reincorporação da ex-República Socialista da União Soviética e da China como elementos plenos do capitalismo mundial.

Em resumo, a desregulamentação do capital e a mundialização do mercado, com a incorporação dos países do Leste e da China, têm um sentido histórico muito intenso para a luta de classes. O moderno sistema do capital livre das amarras que impediam a sua ampla competitividade tem substituído progressivamente a força de trabalho por modernas tecnologias e a produção por capital fictício, parasitário, incorporando economias até então marginais, desencadeando novos conflitos (Chesnais, 2008).

A terceirização é um fenômeno muito objetivo, por meio do qual o capitalismo se livra dos "excessos" dos gastos direcionados à força de trabalho, portanto, é uma das medidas estratégicas de reestruturação do capital. Ela indica claramente o alargamento da subproletarização da classe trabalhadora e, no oposto, a concentração de renda nas mãos do capital, cada vez mais internacionalizado e financeirizado.

A terceirização não é nova. No caso brasileiro, sua perspectiva foi adotada como exigência da globalização econômica, quando, no início de 1990, sob batuta governamental de Collor de Mello, fazendo uso da justificativa de enfrentamento à crise econômica, foram estabelecidas as medidas neoliberais, garantidoras de maior liberdade econômica, não obstante, impôs-se a reestruturação produtiva. Assim, os direitos do trabalho foram taxados de riscos empresariais, muitos deles antes mesmo da sua efetivação. A conclusão é que o desenvolvimento do capital exigiu a abertura comercial e a desregulamentação das relações mercantis, incluindo a mercadoria força de trabalho. As políticas sociais foram elevadas à categoria de privilégios e de impedimentos para o desenvolvimento econômico, diga-se de maior acumulação capitalista.

Nesses quase trinta anos do casamento político e econômico entre neoliberalismo e reestruturação produtiva, mantido e renovado pelos vários governos,

porque o boom imobiliário termina "los préstamos se hacían a hogares que no tenían la menor posibilidad de pagar. Y además, todo eso se combino con las nuevas 'técnicas' financeiras [...] permitiéndose así que los bancos vendieran bonos en condiciones tales que nadie podía saber exactamente qué estaba comprando [...] hasta el fuerte estallido de los 'subprime', en 2007' (Chesnais, 2008, on-line). 
perpassando de Collor de Mello (Partido da Reconstrução Nacional, PRN) a Fernando Henrique Cardoso (FHC) (Partido Social-Democrata Brasileiro, PSDB), com dois mandatos consecutivos (de 1995-98 e 1999-2002) até os governos do Partido dos Trabalhadores (PT), Luiz Inácio Lula da Silva (Lula) (2003-06 e 2007-10) e Dilma Rousseff (2011-14 e 2014 aos dias atuais), desenvolveu-se uma ampla rede da informalidade no país.

A terceirização da produção e do trabalho vem sendo alardeada pelos seus defensores, políticos e empresários, como requinte necessário para a modernização empresarial do país: "Recentemente, conseguimos, por meio de uma luta intensa na Câmara dos Deputados, regulamentar o projeto de lei da terceirização, que garante direitos para 13 milhões de pessoas e fortalece ainda mais os sindicatos quanto da negociação das convenções coletivas (Torres, p. A3).

A habilidosa propaganda ideológica desempenha papel fundamental na construção do consenso social, eliminando, assim, qualquer possibilidade de reação contrária. O discurso de Miguel Torres, presidente da Força Sindical, a par das defesas que vêm sendo feita por Paulo Skaf, ${ }^{6}$ presidente da Fiesp, indica que houve luta intensa na Câmara dos Deputados no momento da aprovação do PL n. 4.330. Tal afirmação encontra-se confrontada, em primeiro lugar, com o fato de que apenas três partidos políticos se posicionaram contra a destruição da proteção do trabalho no Brasil, proposta pelo PL n. 4.330: PT, PCdoB e Psol. Portanto, dizer que houve intensa luta na Câmara dos Deputados é contrassenso, como pode ser visto também na atual composição do Congresso Nacional, que, durante a votação do PL n. 4.330, tornou quase uniforme, se não fosse pelos 137 votos contra e duas abstenções, o eco dos interesses do capital com 324 votos a favor.

São quase 13 milhões de trabalhadores terceirizados no Brasil. Agora, esse número subirá a níveis impensáveis. Essa é a conquista aludida por Miguel Torres! Transformar o maior número possível de trabalhadores em terceirizados é uma vitória de quem ou para quem? Quando as empresas substituem os seus trabalhadores diretos por terceirizados, o que elas procuram não é tornar mais segura as condições de trabalho, mas trata-se da busca por maior lucratividade, isentando-se de maiores responsabilidades com a força de trabalho, que passa a ser contratada por terceiros. Ao resolver os problemas legais pela força da lei,

6. "Depois de intensos debates envolvendo parlamentares, centrais sindicais, entidades patronais, trabalhadores e empresários, pode-se concluir que o substitutivo apresentado pelo deputado Arthur Maia (SD - Bahia), a ser votado, atende de forma equilibrada a todos os setores (Skaf, 2015). 
garante os baixos salários, a frequente rotatividade no trabalho e as piores condições em que este ocorre.

A eficiência administrativa e operacional trazida pela terceirização favorece apenas um elo da corrente, não por acaso, o que já é mais forte: o capital. Trata-se da eliminação de postos de trabalho vinculados às grandes empresas, o que não é o mesmo que fim do trabalho. Isto é um equívoco!? $\mathrm{O}$ que temos não é a abertura de novas vagas, mas a transformação do emprego vinculado às grandes empresas em trabalho terceirizado. É mais trabalho corporificado nas ocupações que aparecem sob o signo de "autônomas" e/ou inúmeras atividades que ocorrem no limbo, nas fabriquetas, nos domicílios aparentemente sem nenhum ligação com a empresa responsável pelo produto final e a "pejotização" de profissionais especializados. Por trás do véu da "riqueza" do trabalho autônomo e do empreendedorismo está a miséria que a terceirização pressupõe.

A terceirização faz coincidir o que aparentemente é distinto, ou seja, é o elo vital entre as empresas automatizadas e os pequenos empreendimentos que funcionam no fundo do quintal, sem nenhuma garantia trabalhista e distantes de quaisquer fiscalização. Eles estão na invisibilidade social e não estão contemplados nos dados dos 13 milhões de trabalhadores oficialmente registrados como terceirizados no país. A precariedade do trabalho é gritante. ${ }^{8}$

Além das questões mais diretamente vinculadas ao trabalho e seu ambiente, a terceirização promove o alargamento dos índices de vulnerabilidade social. Por exemplo, o retorno do trabalho infantil e do adolescente, o rebaixamento salarial, a piora nas condições de trabalho, a extensão da jornada e a maior propensão aos acidentes de trabalho. Na terceirização reside a fonte geradora para muitos outros problemas sociais, como a prostituição e o aumento da precariedade social e da miséria humana. Existem, evidentemente, exceções. Mas, no geral, na base piramidal das relações sociais de trabalho, os terceirizados são aqueles que não têm segurança, seja porque trabalham em péssimas condições, seja porque as empresas terceiras abrem e fecham com muita facilidade, dificultando qualquer garantia trabalhista e perspectiva funcional.

7. Debate já amplamente realizado por Ricardo Antunes. Ver, entre outros, ver Antunes, 1999 e 2010.

8. O setor calçadista em Franca tinha, na década de 1980, 37 mil trabalhadores. Com as prerrogativas neoliberais e da desregulamentação do trabalho, na década de 1990 o seu contingente foi reduzido para uma média de 20 mil trabalhadores (Navarro, 2006), o qual vem se mantendo reduzido mesmo nos momentos de melhora na produção. Essa redução dos trabalhadores formais da categoria de sapateiros não é efeito das inovações tecnológicas, tampouco do fim do trabalho, mas da terceirização. 
Desse modo, busca-se discutir alguns elementos que interatuam para a precarização do trabalho e afetam a saúde dos trabalhadores. Para isso, utiliza-se como material empírico o estudo de um acidente de trabalho ocorrido em uma usina de açúcar e álcool, na época Usina Vale do Rosário, localizada em Morro Agudo, interior do estado de São Paulo, e que estava entre as dez maiores usinas do país. Esse acidente ocorreu em dezembro de 2004 e atingiu 22 pessoas, matando onze delas.

Esta análise, considerando o espaço dedicado a este artigo, compõe-se de estudo do Boletim de Ocorrência (BO) do referido acidente, estudos das notificações dos agravos à saúde dos trabalhadores inseridos nas usinas de açúcar e álcool na região de Franca (SP). E entrevistas com trabalhadores do setor e dos serviços de saúde e sindicalistas que congregam o trabalho nesse setor (químico, alimentício, metalúrgico e dos motoristas), realizadas no período de 2009 a 2012. Mas, aqui, busca-se dar ênfase ao depoimento de um trabalhador terceirizado e que sobreviveu ao referido acidente.

Por fim, deve ser dito que este texto compõe o projeto de pesquisa que procurou quantificar e analisar os acidentes e doenças relacionadas ao trabalho na agroindústria canavieira, no período de 2005 a 2010, na região de Franca (SP). ${ }^{9}$

\section{Os agravos à saúde dos trabalhadores no Brasil e sua não notificação}

O mundo do trabalho na atualidade está eivado de sofrimento. Anualmente, 321 mil pessoas morrem em consequência dos acidentes de trabalho e 2,02 milhões de pessoas morrem em consequência das enfermidades relacionadas ao trabalho, "o que equivale a uma média diária de mais de 5.500 mortes" (OIT, 2013).

O lugar de criação e satisfação tem sido preenchido por técnicas de mobilização da psiquê no trabalho, cuja perspectiva é o aumento da produtividade e a

9. Referência ao projeto de pesquisa "Processo de trabalho e saúde na agroindústria canavieira: os desafios para o Sistema Único de Saúde (SUS) e sindicatos dos trabalhadores", que contou com apoio financeiro do CNPq, conforme processo n. 401159/2010/8, e também foi aprovado pelo Comitê de Ética da Unesp-Franca. Em determinada fase de coleta de dados contou-se com o importante apoio de alguns alunos da Unesp e das professora doutoras Raquel Santos'Ana e Onilda Alves do Carmo, da Unesp Franca, a quem registro profundo agradecimento. As entrevistas, de abordagem qualitativa, ocorreram no período de 2009 a 2012, em geral na residência dos trabalhadores entrevistados ou nas sedes dos sindicatos da categoria a que o entrevistado pertencia. 
intensificação do trabalho. A atual gestão do trabalho utiliza-se de práticas que ferem profundamente a identidade e a dignidade profissionais, determinando que doenças anteriormente restritas a certas ocupações ganhem dimensões epidêmicas, como têm sido os casos de lesão por esforço repetitivo (LER) e os agravos à esfera mental (Alves, 2014; Barreto e Heloani, 2013; Ribeiro, 2013; Seligmann-Silva, 2011).

Encontrando-se no centro da exploração do trabalho e das práticas modernas de administração/gestão e organização laborais, os índices de enfermidades e mortes no e pelo trabalho se assentam menos nos ambientes e muito mais nas relações, as quais compreendem um conjunto de regras e normas que deveriam proteger o trabalho e o trabalhador.

Nos países onde o trabalho costuma ser mais regulamentado e protegido, os riscos laborais são menores. No oposto, nos países e locais onde há maior desproteção, os danos à saúde dos trabalhadores tendem a ser muito maiores. Em geral, estes são os testemunhos de uma legislação trabalhista permissiva, das péssimas condições em que o trabalho ocorre, bem como das relações contratuais agressivas e de baixo investimento em inovações, ciência e tecnologia.

Estas observações têm por finalidade se contrapor à tendência em analisar os acidentes de trabalho como fundados pelo erro humano e/ou por alguma falha de equipamentos e ainda como se fossem ação do destino ou alguma fatalidade. Esse tipo de análise ignora o peso das relações sociais trabalhistas e o efetivo exercício da regulamentação do trabalho e a sua respectiva fiscalização para a segurança do trabalho.

Nestes termos, o Brasil se destaca no ranking mundial de acidentes trabalhistas, ocupando o quarto lugar. Ao considerar as mortes por acidentes de trabalho, tomando como referência o ano de 2000, ${ }^{10}$ segundo a OIT (2013), no Brasil morreram 2.503 pessoas. Assim, o país fica atrás apenas da China (14.924), dos Estados Unidos da América (EUA) (5.840) e da Rússia (2.550). A Tabela I dá algumas informações dos agravos à saúde do trabalhador no Brasil.

10. Segundo a OIT, desde o ano 2000, o Brasil não mais envia à sede da OIT, em Genebra, os seus números de acidentes de trabalho. "Outros dados continuam sendo enviados pelo governo brasileiro e divulgados no Anuário Estatístico do Trabalho da OIT (Yearbook of Labor Statistics), tais como nível de emprego e desemprego, remuneração, horas de trabalho, greves, entre outros. Porém, os registros de acidentalidade não foram mais fornecidos e, por isso, foram mantidos desatualizados por falta de informações. Essa atitude demonstra descaso com as questões de Saúde e Segurança do Trabalho...” (OIT, 2010, p. 84-85). 
Tabela I - Acidentes de Trabalho no Brasil (2011-13)

\begin{tabular}{|c|c|c|c|c|c|c|c|}
\hline \multirow{4}{*}{ Anos } & \multicolumn{7}{|c|}{ Quantidade de Acidentes de Trabalho (2011-2013) } \\
\hline & \multirow{3}{*}{$\begin{array}{c}\text { Total de } \\
\text { acidentes* }\end{array}$} & \multicolumn{4}{|c|}{ Com CAT registrada } & \multirow{3}{*}{$\begin{array}{c}\text { Sem CAT } \\
\text { registrada }\end{array}$} & \multirow{3}{*}{ Óbito } \\
\hline & & \multirow{2}{*}{$\begin{array}{c}\text { Total } \\
\text { Acidentes } \\
\text { com CAT }\end{array}$} & \multicolumn{3}{|c|}{ Motivo/Tipo } & & \\
\hline & & & Típico & Trajeto & $\begin{array}{c}\text { Doença do } \\
\text { trabalho }\end{array}$ & & \\
\hline 2011 & 720.629 & 543.889 & 426.153 & 100.897 & 16.839 & 176.740 & 2.938 \\
\hline 2012 & 713.984 & 546.222 & 426.284 & 103.040 & 16.898 & 167.762 & 2.768 \\
\hline 2013 & 717.911 & 559.081 & 432.254 & 111.601 & 15.226 & 158.830 & 2.797 \\
\hline Total & 2.152 .524 & 1.649 .192 & 1.284 .691 & 315.538 & 48.963 & 503.332 & 8.503 \\
\hline Percentual & & 76,62 & 77,90 & 19,13 & 2,97 & 23,38 & 0,40 \\
\hline
\end{tabular}

Fonte: Tabela construída pela autora a partir do Anuário Estatístico da Previdência Social (2013).

* Total de acidentes inclui os acidentes propriamente ditos e as doenças relacionadas ao trabalho.

Os acidentes de trabalho nos três anos em foco (2011 a 2013) totalizaram 2.152.524 registros. Destes, 1.649,192 foram efetuados por meio da Comunicação de Acidentes de Trabalho (CAT) e 503.332 sem CAT. Do total, 8.503 são óbitos, ou seja, em média, no Brasil, 2.800 pessoas morrem anualmente em decorrência de acidente de trabalho, o que significa 236 mortes ao mês, sete mortes diárias e uma a cada três horas.

Embora seja um número alto, é preciso considerar que esses dados são incompletos frente às reais condições de trabalho. A subnotificação desses eventos se deve a algumas razões muito particulares, primeiramente, estes dados se limitam a determinada parcela de trabalhadores que são cobertos pelo sistema previdenciário e, entre outros, cabe registrar que os serviços de saúde ainda não aderiram a cultura da notificação dos agravos à saúde dos trabalhadores. O Sistema Único de Saúde (SUS) apesar de importantes iniciativas na estruturação da Rede Nacional e Atenção Integral à Saúde dos Trabalhadores (Renast), ainda não conseguiu articular um sistema efetivo de notificação e vigilância em saúde do trabalhador, sobretudo no que diz respeito às doenças relacionadas ao trabalho (Lourenço e Lacaz, 2013).

Outro fator que contribui para a subnotificação dos agravos à saúde dos trabalhadores é a adoção de estratégias empresariais de aportes toyotistas, as quais organizam o trabalho promovendo bonificações para o "presenteísmo" no universo laboral. Reafirmam a competitividade entre os trabalhadores, o cumprimento de 
metas, o engajamento no trabalho e a maior dedicação à empresa. De modo que a preservação desses princípios organizacionais inclui não se ausentar, não se machucar e não adoecer, mesmo que o bem-estar no trabalho seja pura simulação, sendo muito comum chegar em uma empresa e se deparar com um quadro dizendo: "Estamos tantos dias sem acidentes de trabalho".

Portanto, a lesão fundamental desses dados é a sua incompletude. Sobre os principais tipos de ocorrências registradas, observa-se que os acidentes típicos são os que mais ocorrem, embora deva-se prestar atenção também aos acidentes de trajeto. Mas a ênfase recai sobre as notificações sem emissão de CAT, somente proporcionadas pela criação do Nexo Técnico Epidemiológico Previdenciário (NTEP), em 2007, pelo Ministério da Previdência Social. Do total de registros, 503.332 ou $23 \%$ dizem respeito às doenças que foram reconhecidas como relacionadas ao trabalho, sem a emissão de CAT, ou seja, são problemas de saúde vinculados ao trabalho e que muito provavelmente não seriam reconhecidos sem a criação do nexo epidemiológico.

O Anuário Estatístico da Previdência Social de 2013 indica que no período de 2011 a 2013 foram concedidas no país 31.811 aposentadorias por invalidez acidentárias, apenas no âmbito urbano (sendo $10.270 \mathrm{em}$ 2011, $10.651 \mathrm{em} 2012$ e 10.890 em 2013 - Brasil, 2013, p. 114). Verifica-se que o CID V - Transtornos mentais e comportamentais - comparece com $4,68 \%$, ou 1.490 pessoas que perderam a sua capacidade para o trabalho (465 em 2011, $536 \mathrm{em} 2012$ e $489 \mathrm{em}$ 2013). O CID XIII - Doenças do sistema osteomuscular e do tecido conjuntivo - comparece com $31,88 \%$ das referidas aposentadorias - foram 10.142 no total de três anos (3.365 em 2011, 3.465 em 2012 e $3.312 \mathrm{em}$ 2013). Essas duas causas (transtornos mentais e doenças osteomusculares) também comparecem como os principais motivos de auxílios-doença urbanos acidentários (Brasil, 2013, p. 129).

No âmbito rural, foram registrados 64.201 benefícios acidentários rurais, sendo que desse total $3,71 \%$ foram aposentadorias acidentárias. As doenças do sistema osteomuscular e do tecido conjuntivo totalizaram 19.488 casos, ou $33 \%$ do total, e os "transtornos mentais", 239 situações, ou 0,39\% do total (Brasil, 2013, p. 145).

O mito do trabalho leve, informatizado e de maior autonomia é desmistificado nos dados das doenças relacionadas ao trabalho: $25,26 \%$ dos benefícios acidentários (adicionando os segmentos urbano e rural) no Brasil se devem às lesões por esforço repetitivo (LER) e doenças osteomusculares relacionadas ao trabalho (Dort), e quase $4 \%$ referem-se às doenças que atingem a esfera mental. O que isso significa? Que os avanços das forças sociais produtivas materializados 
nas novas maquinarias, consideradas inteligentes e integradas em redes informacionais e automatizadas, associadas aos novos métodos de gerir o trabalho, exigem novas habilidades técnico-operacionais e comportamentais dos trabalhadores, que ferem profundamente a identidade e a dignidade no e pelo trabalho (Seligmann-Silva, 2011). Essas patologias expõem o caráter fundamental do trabalho no sistema capitalista, que é a expropriação contínua e histórica do trabalho (Marx, 2006).

As LER/Dort e os agravos à esfera mental manifestam o desafio de se compreender a saúde dos trabalhadores na contemporaneidade, porque são problemas cujos sintomas e expressões são muito mais difíceis de ser mensurados, quiçá quantificados (Ribeiro, 2013). É muito mais difícil para o trabalhador provar a existência do sofrimento psíquico porque ele é subjetivo, seus nexos são psicossociais, mediados pelas emoções e sentimentos de (in)realização e frustração no/pelo trabalho. A nova gestão do trabalho impõe metas somente alcançáveis à custa da deterioração da saúde, impõe maior envolvimento dos trabalhadores com os ideais das empresas (Alves, 2014), impõe a gestão pelo medo, que segundo Gaulejac (2007), leva os trabalhadores à submissão consentida ao conjunto de técnicas que captam os desejos e as angústias para transformá-los a favor das empresas.

Quadros de ansiedade, depressão, síndrome do pânico e suicídio no trabalho expressam a violência da organização e relações de trabalho na atualidade. A revista Carta Capital lançou um número especial em 2014 a respeito do assédio moral no trabalho, a qual apresenta várias ações na justiça trabalhista denunciando castigos a que estavam submetidos os trabalhadores de grandes empresas, multinacionais e brasileiras, que não cumpriam as metas estabelecidas. Atos de violência, como impor que o funcionário que não cumprisse as metas se acomodasse em um caixão, e outros menos explícitos porque travestidos de premiações, como o absurdo "troféu tartaruga" ${ }^{11}$ além de espionagem e investigação da vida privada dos trabalhadores afastados do trabalho, entre outras agressões que visam atingir o emocional e humilhar os sujeitos.

As patologias contemporâneas vinculadas ao trabalho, como são exemplos as LER/Dort e o sofrimento mental relacionado ao trabalho revelam que o desgaste

11. “As táticas de 'motivação' também são questionadas. Em Mato Grosso, a Renosa, engarrafadora da Coca-Cola, foi condenada em 2011 por distribuir troféus 'tartaruga' e 'lanterna' aos piores funcionários. No mesmo ano, a multinacional brasileira de bebidas Ambev, que já sofreu outras condenações por submeter funcionários a situações consideradas vexatórias, teve de indenizar um ex-funcionário por obrigá-lo a se deitar em um caixão quando não atingia a meta fixada pela empresa" (Carta Capital, 2014, p. 33). 
da vida é muito mais social que apenas biológico. Obviamente a degradação da saúde é biológica (física e mental), mas a sua determinação decorre do peso das relações sociais de trabalho (dentro e fora dele), e a universalidade dessas relações, independentemente dos espaços empresariais — se do setor primário, secundário ou terciário da economia — torna os problemas de saúde daí decorrentes também universais. Por isso, hoje, não se pode dizer que as LER/Dort são problemas que afligem apenas os trabalhadores do setor bancário ou o sofrimento mental se restringe aos professores. Apesar da precariedade dos dados estatísticos dos agravos à saúde dos trabalhadores, o quadro existente indica o nexo causal entre as patologias do trabalho contemporâneo e as atuais relações sociais de trabalho nos mais variados ramos empresariais, urbano ou rural.

\section{Os agravos à saúde dos trabalhadores na agroindústria canavieira}

Ao realizar um estudo acerca dos agravos à saúde dos trabalhadores restringindo-se às usinas de açúcar e álcool da região de Franca, ${ }^{12}$ no período de 2005 a 2010, e notificados aos serviços de saúde das cidades da referida região, obteve-se 2.798 registros. Desses, 837 eram Comunicações de Acidente de Trabalho (CAT) e os demais compunham-se de Relatórios de Atendimento ao Acidentado do Trabalho (Raat)..$^{13}$ Enquanto a CAT é um documento criado pela Previdência Social para registrar os acidentes e doenças do e relacionadas ao trabalho de parte dos seus segurados, o Raat é um instrumento epidemiológico, criado por alguns Centros de Referência em Saúde do Trabalhador (Cerest) para o registro de qualquer agravo à saúde dos trabalhadores (independentemente do seu vínculo empregatício) pelos serviços de saúde (públicos e privados). O Raat é uma tentativa de criar uma cultura nos serviços de saúde em notificar todo agravo relacionado ao trabalho, mas a sua implantação é heterogênea.

12. Considerando a divisão da Secretaria Estadual de Saúde, a região de Franca compõe-se de 22 municípios, compreende um total de mais de 700 mil pessoas e conta com seis importantes usinas sucroenergéticas no seu território.

13. Para o acesso a esses dados foram necessárias inúmeras visitas aos serviços de saúde dos 22 municípios, além de reuniões e encaminhamentos de ofícios aos responsáveis. O estudo das notificações foi feito manualmente, classificando o tipo de acidente, o perfil do trabalhador vítima e dados relativos à ocorrência e Pa ocupação, conforme informações contidas nas Comunicações de Acidentes de Trabalho (CAT) e Relatório de Acidentes de Trabalho (Raat). 
Sobre o perfil dos trabalhadores que sofrem agravos à saúde nesse setor destaca-se que $90 \%$ dos registros estudados referem-se aos trabalhadores do sexo masculino. Soma-se a essa característica o fato de a grande maioria dos trabalhadores ser jovem, 40,28\% têm entre 24 e 29 anos (se se adicionar a esse o grupo etário subsequente, de 30 a 35 anos, têm-se mais se $60 \%$ do total das notificações dos agravos).

Verifica-se que as ocorrências no campo, ou seja, na lavoura de cana-de-açúcar constituíram 2.364 situações, ou 84,49\% dos registros; as ocorrências no interior das usinas somaram 409 notificações, ou 14,62\% dos dados ora estudados. $\mathrm{Na}$ sua maioria, os registros indicam que se trata de ocorrências leves, sendo que 22 notificações são de mortes no trabalho, duas delas ocorridas no interior das usinas e as demais no trajeto.

Observa-se que 133 , ou $8,78 \%$ das notificações, indicaram genericamente que os agravos ocorreram na "usina", sem precisar onde ou em qual setor teria ocorrido o agravo. Quanto aos setores de maior frequência de acidentes, devidamente identificados no interior da usina, se destacam: "Oficina”, com 55 notificações, ou 2,59\%; "Armazém de Açúcar”, com 24 registros, 2,01\%; "Pátio", 15 agravos, 1,25\%; "Extração do Caldo", 13 situações, 0,59\%; ao adicionar a esse total oito agravos ocorridos na Moenda, obtém-se 21 registros, ou 0,75\%. A "Caldeira" apareceu com 12 situações ou 1\%. Outros setores tiveram registros inferiores a dez situações.

É importante dizer que o corte manual da cana-de-açúcar manteve a maior constância nos registros ora estudados. Os eventos ocorreram com mais frequência no final da safra e muito provavelmente expressam o esgotamento intenso que esses trabalhadores estão submetidos (Sant’Ana, 2012). Novaes (2007) já havia feito a relação dos acidentes de trabalho entre os cortadores de cana e o cansaço por eles sentido. Portanto, não é exagero afirmar que eles podem também desenvolver doenças relacionadas ao trabalho, mas o seu reconhecimento e registro são sempre muito difíceis e, por vezes, protelado. E quando buscam tratamento para esses problemas, em geral, são vistos como desgaste natural da vida, sem qualquer relação com o trabalho.

As empresas utilizam várias estratégias para negar os direitos dos trabalhadores, sobretudo se o trabalhador adoece. Elas disseminam o medo, implementam novas tecnologias acompanhadas de "novos" métodos de gestão, os quais buscam maior controle, assiduidade e maior produtividade por parte dos trabalhadores. As políticas de saúde e segurança no trabalho, desenvolvidas por essas empresas, geralmente são repressivas. 
O índice de acidentes de trabalho de uma empresa pode determinar a participação não apenas de um trabalhador, mas de toda uma equipe, nos lucros e resultados (PLR): “[...] que dizer se acidentou, se abriu CAT, para eles perdem um percentual da PLR [Participação nos Lucros e Resultados], ou um acidente ou dois... é proporcional ao número de acidentes... Então, tem uma relutância para abrir uma CAT" (Entrevista com soldador/Usina, Leo). A prevenção, contraditoriamente, vincula-se a sua própria causa, ou seja, aos estímulos para maior produtividade.

Verifica-se a estratégia de vincular a assistência/reconhecimento e repressão. Algumas empresas têm premiado os trabalhadores por equipe, desde que mantenham índice zero de acidentes de trabalho. Os prêmios podem ser folgas remuneradas, troféus e participação nos lucros e resultados. A repressão vai desde a advertência até a demissão! A usina Alta Mogiana, especificamente o setor de qualidade, está há dezesseis anos sem acidentes de trabalho. Portanto, os trabalhadores desse setor têm direito a folgas remuneradas do trabalho, proporcionais ao seu tempo de serviço. "Essa solução visa premiar o trabalho da equipe, pois caso ocorra um acidente com afastamento, todos do setor perdem a conquista dos dias de descanso" (Vicente, 2012).

Na corrida pelo marketing social, as empresas têm buscado, cada vez mais, se enquadrar nos padrões ditados pela International Standards Organization (ISO), o que tem implicado critérios para a execução de atividades, maior treinamento, readequação das instalações físico-ambientais. Contudo, a introdução da automação e dos novos métodos de gestão empresarial tem primado pela redução do trabalho vivo e da instauração de um clima psicológico, que articula o medo, a insegurança e a desconfiança entre os trabalhadores, o que afeta a saúde mental deles, embora esses problemas de saúde, na maioria das vezes, fiquem distante dos dados estatísticos.

Constata-se que o trabalho no interior das usinas exige experiência, conhecimento técnico e qualificação. Sem esses atributos, os trabalhadores ficam mais suscetíveis aos agravos, inclusive aos acidentes fatais. Contudo, as usinas usam como estratégias a contratação de ocupações pouco qualificadas e da terceirização, num sistema rotativo da força de trabalho, o que favorece maior exposição aos riscos.

A terceirização, até então, limitava-se apenas às atividades-meio, ou seja, no caso das usinas, era utilizada para a manutenção industrial, em especial a desmontagem e remontagem da indústria, que ocorre no período da entressafra e manutenção permanente das máquinas e respectiva limpeza: 
É eu fui empregado pela firma de Orlândia, que presta serviço para a usina. O meu trabalho é na usina, eu fazia tudo na usina, mas quem me pagava era a outra firma, a que me contratou. Eu acho isso aí muito errado, porque eu trabalhava na usina, recebia todas as ordens da usina, mas o meu salário vinha da outra firma. Eu trabalhava igual a todo mundo, até mais, mas eu não tinha os mesmos direitos que os que eram da usina (Guido).

A terceirização segmenta os trabalhadores e o seu imaginário de classe. O trabalhador entrevistado destaca a terceirização como uma injustiça, à medida que provoca uma diferenciação entre os trabalhadores da usina e os da firma terceira, sentida inclusive nos vencimentos e no acesso aos benefícios: “[...] as ordens de serviço, as normas eram da usina, só que meu uniforme era diferente e quem pagava era a Zana [firma terceirizada]" (Guido). Os trabalhadores terceirizados não têm acesso aos mesmos direitos que os contratados diretamente pelas usinas. "O uniforme era de outra cor, era verde, e o dos funcionários era cinza... o funcionário terceirizado usava um tipo de banheiro e o da usina era outro... $\mathrm{O}$ banheiro era muito ruim, agora eu não sei como está, mas na época era muito ruim (Idem). O trabalhador terceirizado explicita a diferença entre trabalhadores da usina e terceirizados:

[...] por exemplo, se ia ter uma festa lá..., ia ter a festa das crianças só iam os filhos dos funcionários da usina. Até no clube, para você ver, no clube da usina, às vezes, o pessoal marcava de levar a família, de fazer uma festinha, jogar uma bola, a gente só escutava e não podia participar, os terceirizados só podiam era trabalhar mesmo, tinha vez que tinha um colega que oferecia - "Ô, você quer ir, eu pego convite pra você" —, mas se ele pegasse pra mim faltava pra família dele, então eu não ia (Guido).

As usinas de açúcar, álcool e energia têm se tornado grupos oligopolizados, politicamente influentes, sobretudo nos pequenos municípios, onde a monocultura e as relações imperantes situam o trabalho como artigo raro. Essas empresas fazem uso do trabalho desqualificado, mesmo para as atividades industriais, onde a nocividade do trabalho é mais iminente.

A terceirização aumenta a vulnerabilidade do trabalho e efetiva uma cisão entre os contratados diretos pela usina e os terceiros, o uso diferenciado dos banheiros e da cor do uniforme, expressa "quem é da usina e quem é terceirizado". Essa variação na contratação é uma estratégia para a maior acumulação e acaba por 
conformar as relações sociais trabalhistas, sem muitas condições de alteração ou de reação contra a exploração e a alienação no trabalho.

É, essa firma que eu trabalhava, ela tinha outro problema, todo ano ela obrigava nós a dar baixa na carteira e registrava de novo, [...] só que ela mudava o nome da firma..., então, tinha uma que era no nome do pai dele, outra no nome da filha dele, eram três firmas e, cada ano, a gente era contratado por uma... Agora, tem outro problema... quando a gente ia acertar, eles falavam assim: "Nós pagamos a metade e outra metade a gente vai depositar". Então..., a multa de $40 \%$... eles tiravam do pagamento e falavam: "Porque isso aqui eu tenho que depositar lá, são obrigações com o Estado, mas esse dinheiro você vai pegar lá no seu fundo de garantia". [...] quer dizer, eles pagavam $20 \%$, porque os outros $20 \%$ eles tiravam de nós pra depositar lá. E depois do acidente não deu mais baixa porque não pode. E depois do acidente eu estava registrado direto. (Guido)

A perspectiva e maior estabilidade devido ao tempo de trabalho fica totalmente inviabilizada, assim como o tempo de serviço, a experiência profissional e o treinamento. Observa-se que há sucessivas contratações, o trabalhador continua na mesma empresa, mas a contratante vai sendo trocada. O processo de contratação, além de agredir visivelmente a garantia dos direitos trabalhistas, também inviabiliza o reconhecimento das empresas que mais agridem a saúde, perde-se a relação de história profissional com a empresa.

Os salários dos trabalhadores terceirizados também são diferentes da negociação coletiva garantidos pelo Sindicato da Alimentação ou dos Químicos (Thomaz Jr., 2002). No interior das usinas, as formas de pagamento acabam sendo tão complexas quanto aquelas vivenciadas na lavoura, onde o salário do cortador de cana é por produção, cuja forma de contabilizar é a transformação da cana cortada em metros para toneladas, o que acaba sendo uma incógnita para os trabalhadores (Alves, 2006). No interior das usinas, além das funções de serviços gerais, ajudantes e auxiliares, sobressaem as funções de soldador, operador, mecânico, encanador, entre outros, que têm graduações salariais diferenciadas. Por exemplo, se o profissional é de nível I, II ou III, em geral o pagamento é por horas e acompanha o grau da especialização. Os documentos apontaram para os valores em horas.

Os terceirizados não têm acesso aos benefícios conquistados pelos trabalhadores da usina, como participação nos lucros e resultados, adicional noturno, insalubridade, custeio de cursos, entre outros. É um trabalho rotativo. 
Era só para quem era da usina. Tudo a gente tinha que ver com o dono da firma [terceirizada], não lá na usina. [Então, nos três anos que você trabalhou dentro da usina, antes do acidente, você não recebeu a PLR?] Não, a gente até falou com o empreiteiro..., mas nós não tínhamos direito naquilo ali por causa do contrato... no final do ano, quando ela [usina] dava um monte coisas para os funcionários dela, dava cesta básica, levava brinquedo para os filhos dos funcionários dela e nós não recebia nada e era só com o salário mesmo. E o pior é que você fica com vergonha diante dos outros [empregados da usina], porque tinha aqueles que fazia graça e falava assim: "Ô, você não vai buscar o seu? Ah, você não pode" (Guido)

A terceirização é um poderoso meio de reduzir a porosidade do trabalho, aqueles períodos em que a produção cai, as suas interrupções ou "tempo morto". É um poderoso meio de negar o acesso aos benefícios garantidos nos acordos coletivos e de reduzir as contratações de trabalhadores especializados, com maior poder de ganho. Se o trabalhador presta serviço por um curto período, não há tempo hábil para questionar a organização, tornando o trabalho muito mais inseguro do ponto de vista da saúde do trabalhador.

No interior das usinas existem inúmeras situações que podem causar problemas sérios e fatais durante o trabalho, e como a terceirização faz com o que o trabalhador atue em lugares diferenciados em curto espaço de tempo, inviabiliza a experiência profissional naquele espaço e, em consequência, as reivindicações por melhores condições. Além disso, o tratamento e o diagnóstico dos problemas que se referem à degradação mais lenta da saúde muitas vezes ocorrem quando o trabalhador já não desenvolve mais a atividade em determinado setor. Portanto, o vínculo entre os agravos relacionados ao trabalho e determinado setor produtivo fica extremamente prejudicado.

Há um fetiche em torno da usina no imaginário dos trabalhadores, sobretudo da área rural, que manifesta um desejo pelo trabalho no interior da indústria. No geral, os trabalhadores dos pequenos municípios onde esses empreendimentos se instalam, premidos pela falta de emprego, veem nas usinas a grande oportunidade de trabalho. A ilusão cresce com os supostos benefícios que são oferecidos, como: usar o restaurante da usina, o clube da cidade, ter uma remuneração fixa, ser registrado e ter trabalho o ano todo, trabalhar num ambiente "limpo", ter participação nos lucros e resultados, receber apoio para fazer algum curso. Tudo isso amalgama o desejo de ascensão dos trabalhadores rurais à indústria. Mas a terceirização desmantela todas essas possibilidades. 


\section{MEMÓRIA DE UM SOBREVIVENTE DE ACIDENTE DE TRABALHO}

Para uns, a cana é doce, para outros, a maioria, ela é áspera (Ianni, 1977, p. 24).

\section{Como foi o acidente}

Eu estava trabalhando, tinha acabado de almoçar e eu subi lá pra cima, na fábrica de açúcar. [...] eu, o ajudante e o soldador e aí eu estava perto desse trem, desse evaporador que estourou. Ele fica dentro da fábrica de açúcar. Eu tava lá perto, eu faço o serviço e o soldador vai lá e solda. Eu acabei de fazer o serviço e o soldador foi soldar e aí ficamos, eu e meu ajudante..., de repente veio aquele estouro... e o prédio deu uma tremedinha assim trurururrur, balançou, e como eu trabalhava lá um pouquinho mais de três anos e nunca tinha visto aquilo, só deu tempo de eu falar para o meu ajudante: "Oh, corre"! [...] foi uma questão de cinco segundos, não foi mais que isso, porque... já senti o vapor bater nas minhas costas e, na hora, eu caí no chão... e já veio aquele monte de garapa e não dava para ver nada, tudo branco por causa do vapor... Eu consegui levantar, mas não dava para ver nada na palma da mão, não dava para ver nada e nem respirar. Você já pôs a mão no vapor de água fervendo? Já viu como é quente? Então, só que não era só na mão, aquele vapor pegava o corpo todo. Eu não conseguia nem respirar [...] na hora que eu saí, olhei e vi os meus braços, nossa! A pele daqui [do ombro] tinha descido e ficou dependurada, ixe! Eu fiquei apavorado. [...] eu comecei a gritar e saí correndo. Pensei: eu consegui sair lá de dentro, os outros não conseguiram, eu saí primeiro, os outros lá morreram. A hora que eu... fui à enfermaria da usina $\mathrm{e}$ cheguei lá, eu vi aquele mundo de gente, todos queimados, eu fiquei apavorado. Foram tirando minha roupa, me deixaram de cueca, a pele aqui [coxa] também desceu e do meu pé também, é porque a garapa veio e entrou dentro da botina e ficou cozinhando a sola do pé, e a hora que eles tiraram minha botina, essa sola minha aqui [parte inferior do pé] saiu; agora já reconstituiu, mas na hora ficou dependurado daqui [calcanhar] pra cá. Ó, ela desencaixou essa parte grossa aqui... ixe, não gosto de nem de lembrar [emociona-se]. Mas, fiquei apavorado mesmo quando vi aquele monte de gente queimada. Aí eu já pensei: a usina só tem uma ambulância; na minha cabeça, eles vão levar primeiro os da usina [o trabalhador é terceirizado]. Eu vou morrer aqui! Então não sei o que me deu, acho que foi desespero, e saí correndo para saída da usina.

\section{Como você conseguiu chegar ao hospital?}

Ixe! No apavoramento, eu pensei que ia morrer, por isso, saí correndo até lá... a sola do pé desencaixava e encaixava, estava na carne, é a mesma coisa que você vestir um sapato molhado e fazer aquele barulhinho nheque, nheque... Mas, para apavorar ainda mais, na saída eu encontro uma mulher que trabalhava lá na usina, que estava socorrendo a outra mulher e eu falei: "Pelo amor de Deus me leva também!". A mulher não 
quis me levar... Isso aí me deixou mais apavorado e eu voltei lá para chapeira [guarita localizada na entrada da usina] e tinha a salinha dos guardas que tinha ar-condicionado e eles falaram: "Entra aqui, entra aqui", e eu entrei nessa salinha... Só de cueca, com tudo queimado com a pele dependurada... e logo veio um rapaz que era segurança lá da usina e ele me viu e me pôs no carro e foi. Eram umas três horas da tarde, o sol estava muito quente, nunca vi um sol quente daquele jeito. $\mathrm{O}$ vidro do carro dele era elétrico e eu fechava o vidro..., mas estava muito quente, então, abria o vidro, mas também não aguentava o mormaço quente e pedia para fechar, e assim foi até chegar no hospital. Mas demorou, parece que demorou muito... E chegando lá, em Orlândia, outro problema: a gente não conseguia entrar no hospital, porque tinha muita gente dentro e na porta do hospital..., o povo tinha juntado lá para saber se tinha parente e ninguém dava informação..., virou um tumulto. Tinha muito curioso também... As enfermeiras não sabiam o que fazer... e já não tinha maca para deitar quem tava chegando, me deitaram no chão... Eles começaram a jogar soro e depois aplicaram injeção contra tétano... depois veio outra e me deu outra injeção. Eu tomei duas injeções, para você ver o tamanho do apavoramento das enfermeiras. Eu pensei: não vou pegar tétano tão cedo. Depois demorou, aquela gritaria do povo, até que me colocaram numa maca e me levaram para a sala de cirurgia. O médico me deu uma injeção e eu apaguei e fui acordar em Ribeirão Preto... Graças a Deus eles conseguiram vaga para mim em Ribeirão Preto, [Hospital das Clínicas] é a melhor Unidade de Queimados. Mas o pior da queimadura não é a queimadura, é o tratamento... eu fiquei sofrendo dor um mês direto, a injeção que eles me aplicavam não fazia mais efeito... O banho é muito dolorido, eles tiram tudo e o corpo cheio de bolha, eu tinha que entrar na banheira. Parece que é tão simples, é só chegar e entrar. Nossa, mas era difícil, eu tinha que ir andando e só não estava queimado debaixo do braço e eu tinha que entrar nessa banheira, tudo queimado e não tinha jeito de mexer nada. Era turbilhão [banheira], entrava no turbilhão de ferro assim. Lá dentro tinha um jato do lado de cá e do lado lá, e quando ligava esse jato e fazia só chuuu, é como se fosse uma banheira de hidromassagem..., ela é morna e na hora que eles ligavam, você sentia a pele sair, a pele morta, aquilo parecia um liquidificador, a água rodando... Eu fiquei setenta dias internado e fazia isso todo dia. Eu fiquei Natal, Ano Novo, Carnaval. Eu passei tudo isso lá e depois que saía daquela banheira, nossa, era um alívio!

\section{E os seus amigos de trabalho, eles estavam com você?}

Eu tive muita sorte porque o acidente foi muito feio, eu só vim saber de tudo mesmo, dos meus amigos, depois que eu saí de lá [hospital]. No ato, no dia, morreu um, foi o velho que trabalhava no cozimento do açúcar que morreu, a garapa caiu em cima dele como se fosse uma cachoeira e ele ficou lá na escada, mas divulgaram a morte dele só à noite, e foi soltando uma morte por dia; agora, não sei porque cada dia morria 
um... O médico do hospital me disse que se a pessoa tiver 70\% do corpo queimado só sobrevive por milagre de Deus, porque pela medicina não. Mas eles fazem de tudo para salvar, [...] um rapaz da usina que estava no hospital comigo me marcou muito..., a mulher dele estava grávida e ele queimou o corpo inteiro; só não queimou a parte da cabeça porque ele usava capacete. Ele estava consciente, mas gritava direto, a enfermeira dava injeção para ele não sentir aquela dor e de noite, quando ele acordava, ele dava cada grito, ele gritava e eu escutava aquele grito e assustava. Ele pensava que ele ia sair no Natal. Ficava dizendo: “A minha mulher está grávida, quero ver meu filho". E quando foi Natal, justamente no Natal, ele morreu. Ele pensou que não fosse morrer; ele falou: "No Natal, eu vou sair porque a minha mulher está grávida, quero ver meu filho, que está nascendo". Isso me marcou muito. O meu companheiro de trabalho, meu ajudante, ele não conseguiu sair, ele morreu. Agora o soldador, ele não queimou muito não, porque o soldador usa um monte de equipamento, ele usa manta, luva, avental, máscara e capacete. Acho que isso ajudou; o que ele mais queimou foi a perna. Mas teve outro soldador que estava lá em cima, quando a garapa começou a cair nele, ele se jogou, estava queimando; então, ele se jogou..., além de ele se queimar, ele bateu a cabeça também. Morreu também uma faxineira, dois pedreiros e mais dois amigos meus. Teve também uns que morreram que eram gerentes. Tinha o escritório central que era ao lado da fábrica, e com a explosão estourou os vidros e entrou garapa e vapor quente queimando todo mundo, patrão e empregado. Pegou nas costas deles, não teve como fugir. Justamente naquela hora eles estavam tendo reunião. Mais gerente ia morrer. É que na hora deu um apagão de força [energia elétrica], e um gerente saiu para ver o que tinha acontecido, o sr. Osnir [nome fictício] e mais outro. Se eles não saem, teriam morrido também. Ao todo morreram onze pessoas, mas muita gente ficou machucada, com sequela. (Guido)

O acidente ocorreu em dezembro de 2004, na usina de açúcar e álcool, na época Vale do Rosário, localizada em Morro Agudo (SP), hoje de propriedade do grupo francês LDC Sev. A safra e a consequente manufatura industrial da cana-de-açúcar em geral se estendem, no estado de São Paulo, até final do mês de novembro. Portanto, o referido acidente ocorreu num momento de sobrecarga e exaustão industrial.

O engenheiro de Segurança do Trabalho afirma, conforme Boletim de Ocorrência (BO), que, na entressafra, todo equipamento da usina é desmontado por uma empresa especializada, contratada para esse fim, a qual, após a manutenção, fornece laudo do equipamento e do trabalho feito. Refere também que não tinha tido nenhuma reclamação por parte dos trabalhadores quanto a irregularidades no sistema de evaporação. 
Observa-se a impotência dos serviços de saúde frente aos acidentes de trabalho, além do desespero do pessoal da enfermagem frente ao grande número de queimados, citado pelo entrevistado. $\mathrm{Na}$ época desse acidente a pesquisadora atuava como assistente social do Centro de Referência em Saúde do Trabalhador (Cerest - regional Franca) e pôde constatar que, antes de qualquer coisa, os serviços de saúde carecem de um sistema de notificação eficaz, para que todo agravo à saúde seja registrado, bem como de um sistema de vigilância. Carecem de equipes tecnicamente preparadas para atuar na investigação de acidentes de trabalho e propor medidas de proteção à saúde.

As maiores informações desse acidente, além da entrevista com um sobrevivente, ocorreram por meio do BO. Nele é possível apreender informações oferecidas por vários funcionários da usina. ${ }^{14} \mathrm{O}$ acidente foi desencadeado pelo rompimento do fundo de um equipamento denominado pré-evaporador $\mathrm{I},{ }^{15}$ que despejou grande quantidade de caldo de cana-de-açúcar, com temperatura entre de $110^{\circ} \mathrm{C}$ e $120^{\circ} \mathrm{C}$, e atingiu 22 pessoas que estavam trabalhando nas proximidades. Lê-se no BO que "a segunda testemunha acima citada é que estava operando o equipamento no momento do acidente, sendo que nada sofreu, vez que o comando ocorre na parte de cima do equipamento. Não foi possível informar a quantidade de caldo de cana-de-açúcar que vazou, mas foi relatado que a capacidade do tanque do pré-evaporador é de $3.500 \mathrm{~m}^{2}$ de área" (BO, p. 2).

O supervisor da Produção de Açúcar explica, conforme BO, que no interior do pré-evaporador o caldo da cana-de-açúcar recebe aquecimento, com vapor de escape, com temperatura entre $125^{\circ} \mathrm{C}$ e $127^{\circ} \mathrm{C}$, sendo que o pré-evaporador é acionado por pressão. Assim, há um sistema de válvulas individuais em cada equipamento, e no coletor as válvulas são acionadas automaticamente para aliviar o excesso. Informa também que nesse setor atuam dois funcionários por turnos de oito

14. As ocupações atingidas pelo acidente foram: auxiliar de dentista, gerente operacional, operador de caldeira, coordenador agrícola, líder de produção, operador de armazém de açúcar, gerente de transportes, serviços gerais (duas pessoas), ajudante (duas pessoas), encanador (duas pessoas), soldador e ainda duas pessoas nas funções de pedreiro e servente. $O$ fato de ter atingido uma sala localizada ao lado da fábrica de açúcar fez com que algumas pessoas que estavam em reunião também fossem atingidas, mas as vítimas compuseram-se substancialmente de trabalhadores ligados direto à produção ou que estavam atuando na reforma, como é o caso das funções da construção civil, conforme se lê na relação das vítimas no BO (p. 67-69).

15. "O pré-evaporador é constituído de três partes, ou seja, o fundo, a calambra e o corpo, sendo certo que o acidente se deu com o rompimento do fundo...” (BO, p. 25-26). 
horas cada, os quais têm acesso ao pré-evaporador e fazem a checagem da pressão, temperatura e o nível do equipamento. Esses dados também são acompanhados por um sistema informatizado.

O depoimento do operador do pré-evaporador registra que, no dia do acidente, havia ocorrido limpeza no equipamento, a qual é feita semanalmente por uma empresa terceirizada, e que nada de anormal foi relatado. No BO encontra-se também o depoimento do proprietário da empresa contratada para a limpeza do pré-evaporador I, o qual afirmou que a sua empresa está no ramo de limpeza de pré-evaporadores, evaporadores e aquecedores há dez anos, sempre prestando serviços às usinas de açúcar e álcool. O trabalhador entrevistado para este estudo, Guido, desenvolvia a função de encanador na referida usina havia três anos e era contratado por essa empresa terceirizada para atuar como encanador, trabalhando diariamente na referida usina.

O proprietário da empresa terceirizada, que faz a limpeza nos equipamentos industriais, mantém uma equipe de dezesseis funcionários diariamente dentro da usina, conforme consta no BO. Afirma também que no dia do acidente havia sido feita a limpeza e não foi observada nenhuma intercorrência. A limpeza do pré-evaporador é feita com o equipamento desligado e aberto, o que é providenciado pelos funcionários da usina. Os trabalhadores entram no interior do pré-evaporador pela "boca de visita", quando é feita a limpeza dos tubos que compõem o equipamento e no fundo deste, o qual se soltou no dia do acidente. ${ }^{16} \mathrm{Um}$ trabalhador da fábrica de açúcar "informa que algum tempo antes do acidente houve uma queda de energia, e depois que a energia voltou, tudo estava funcionando normalmente" (BO, p. 53), o que também foi informado por Guido.

No laudo do Instituo de Criminalística, o excesso de sobrecarga seria a causa do referido acidente: "Concluem os relatores que tanto a solda das chapas de aço quanto o mencionado tubo romperam em função da ocorrência de esforços superiores aos que as peças podiam suportar (fraturas dúcteis) (Instituto de Criminalística, relatório anexado no BO, p. 217). O relatório do Instituto de Criminalística destaca ainda que "as respectivas explicações para a ocorrência de tais esforços, no

16. Em julho de 2007, outro acidente ocorreu no pré-evaporador na mesma usina, atingindo dezesseis pessoas, as quais faziam a limpeza do equipamento "Quinze trabalhadores se feriram ontem em decorrência do vazamento de caldo de cana quente na Companhia Açucareira Vale do Rosário, em Morro Agudo. Três seguiam internados ontem à tarde no Hospital Especializado de Ribeirão Preto sem risco de morte... O acidente aconteceu por volta das $8 \mathrm{~h} 15$, mas a polícia só foi chamada por volta das 11 horas" (Vazamento, 2007). 
entanto, escapam às possibilidades de exame deste laboratório, uma vez que examinamos apenas as peças aqui recebidas, sem termos tido contato com o restante do equipamento de onde foram retiradas" (Idem). O acidente ocorreu em seis (6) de dezembro, mas a safra geralmente se encerra em novembro, o que pode ter contribuído para a sobrecarga do pré-evaporador.

\begin{abstract}
$\mathrm{Na}$, minha opinião, eu penso assim, na safra passada mexeram no pré-evaporador, para aumentar a capacidade, a usina pôs um gerador para aumentar a capacidade e, quer dizer, que aquele tipo assim: a perícia nem viu, fez perícia, tanta perícia lá, e acho que não viu isso aí. Vou explicar: o pré era menor, eles tinham mudado a estrutura dele, só que para cima a parte de baixo continuou pequena; é a mesma coisa se cortar essa casa no meio e levantar para cima... e aumentar os canos na parte de baixo e aumentou em dobro a tubulação de saída, vai passar mais vapor, mais pressão. Foi o que aconteceu, quer dizer, eu aumentei essa casa e o fundo continua o mesmo, mas com mais pressão, altura maior e o fundo o mesmo. O que acontece? Igual, se eu pegar a partir de amanhã, se eu construir uma casa em cima dessa sendo que o alicerce não foi feito para isso, futuramente essa casa não vai aguentar. E aí, quer dizer, erguendo para cima o fundo continua o mesmo, o fundo feito para aquele tamanho, quando eles compraram o pré, o fundo veio com aquele tamanho, aí se futuramente ele é aumentado, tem que trocar o fundo também. Quer dizer, eles aumentaram a produção e precisavam de um pré maior; então, eles resolveram partir do que já tinham, mas o fundo não aguentou, ele rachou inteirinho... (Guido)
\end{abstract}

O depoimento permite radicalizar a discussão para além da visão hegemônica dos técnicos e demais profissionais que se restringem as análises dos agravos à saúde a determinados riscos isolados e presos ao ambiente físico e das máquinas e, ainda, ao fator humano. O trabalhador afirmou que ocorreu uma adaptação no pré-evaporador dilatando a sua capacidade para armazenar mais caldo. Contudo, sem a modificação adequada, o fundo não suportou e rompeu, matando onze pessoas e deixando outras onze feridas que não se sabe se vieram a óbito, considerando que queimaduras podem trazer complicações muito sérias, além das sequelas psicológicas e deformações do corpo. ${ }^{17} \mathrm{~A}$ memória da tragédia,

17. Neste sentido, não é possível se esquecer de uma fotografia que Guido, o trabalhador entrevistado, fez questão de mostrar à pesquisadora. Tratava-se de uma foto tirada antes do acidente, na qual era possível visualizar o físico bonito de um jovem de pouco mais de vinte anos, que após o acidente ficou com sérias sequelas e deformações. 
a convivência com as recordações, com as lembranças dos companheiros de trabalho que não resistiram ao acidente, tudo isso, também pode ser motivo de grande sofrimento.

\section{Como você está, como se sente, depois disso tudo?}

$\mathrm{Eu}$, hoje, estou bem, já melhorei muito..., mas tem dia que eu penso que vou morrer, tenho dores horríveis de cabeça, fico internado uns três dias, tomando injeção, daquelas forte, e os médicos não sabem o que eu tenho. O médico fica sem saber o que fazer comigo, porque já deu todo medicamento e a dor não para; depois que eu saio do hospital a minha cabeça ainda dói uns vinte dias; então, quando ela vem, eu acho que vou morrer. Eu vou te falar uma coisa: antes de acontecer isso eu não tinha dor de cabeça, foi depois do acidente que começou a me dar essas crises... Sei lá, agora já me acostumei do jeito que eu estou, mas aqui [mostra o braço] aqui não tem jeito de melhorar nunca mais, a tendência é só piorar, repuxar. Esse dedão aqui [polegar] já está repuxando. O médico que me acompanha falou que eu tenho que operar porque o meu dedo [polegar] não fecha, está dando um cordão aqui...

[...] eles me indenizaram, eu tive que entrar na justiça porque falaram que não iam indenizar, nós, do Zé Canela [empresa terceirizada pela usina], por isso, entramos na justiça e nós ganhamos. Eu comprei essa casa. Eles também me davam assistência, me levava e buscava, porque o tratamento é todo feito em Ribeirão Preto, mas agora mudou... Está meio complicado, tudo depende de autorização... (Guido)

O trabalhador informou que recebeu uma indenização, que, na época, lhe possibilitou a aquisição de um pequeno imóvel, mas como foi necessário ação na justiça, 30\% do valor recebido foi para pagar o advogado. A reparação material, embora sempre insuficiente, é importante, como também o apoio da empresa quanto a manutenção do convênio médico, a liberdade de tratar com o especialista desejado e a garantia do acompanhamento psicológico e do transporte para o tratamento, que, no caso, é realizado em outra cidade. Com a venda da usina, esse apoio estava sofrendo restrições: "Até agora a usina me deu assistência, mas agora mudou porque os donos mudaram e eles querem passar nós [ele e outros colegas vítimas de acidentes] para outro médico, não quer mais o médico que sempre acompanhou..." (Guido).

Pesa sobre as condições de vida dos trabalhadores que perdem a sua capacidade para o trabalho, a impotência, a dor da perda e a convivência com os limites diários postos por um trabalho que, quando não mata, deixa sequelas. 


\section{Considerações finais}

O fundamento que pode sob todas as luzes ser admitido para a efetiva saúde dos trabalhadores é a garantia da dignidade da pessoa humana, dos valores éticos e de normas que limitam a exploração do trabalho. De outro modo, como garantir minimante a segurança no trabalho?

A terceirização concentra renda e aumenta o poder das grandes empresas, que passam a usufruir do trabalho das empresas subcontratadas, pagando salários mais baixos, eliminando os gastos com a responsabilidade dos direitos sociais e trabalhistas. Portanto, não contribuem com a formação do fundo público; isentam-se de manter os benefícios, como a participação nos lucros e resultados, entre outros.

O discurso apregoado por Paulo Skaf, Miguel Torres e demais, é falso. A Lei n. 4.330 revela a ignorância, na verdade, a arrogância dos legisladores e donos do capital, que pensam em produzir modernidade pelo avesso. O trabalho é o ordenador das relações. Por exemplo, uma família projeta os seus sonhos, as suas expectativas de futuro, a sua morada, a formação dos seus membros por meio do trabalho e respectivos vencimentos. Não se promove desenvolvimento sem oferecer garantias de trabalho e de acesso às políticas sociais básicas, como saúde e educação. Sem isso, o que se tem é concentração de renda, que mantém uma pequena parcela da sociedade em segurança nas várias esferas, desde a alimentar até as mais futilidades consumistas, enquanto a grande maioria vive na insegurança. Insegurança do trabalho precipita as crises sociais, manifestadas nos mais diversos problemas, que vira e mexe não se sabe como enfrentá-los, como é o caso da cracolândia e do aumento da demanda para o sistema carcerário. Quanto menos direitos, maiores os problemas sociais.

O exercício de pesquisar e pensar sobre determinada realidade se torna também um ato dolorido, quando se constata que a vida de muitos é totalmente banalizada ante a busca irrefreada do capital pela sua acumulação. Trabalhadores jovens que passam a conviver com sequelas para o resto da vida, como é o caso de Guido. Ao constatar a vulnerabilidade que o sofrimento impõe às vítimas do trabalho, seja pelos acidentes e doenças relacionadas à ocupação, seja pelo desemprego, como já abordado em estudo anterior (Lourenço, 2013), o pesquisador não está imune e se sensibiliza com essas histórias, que, muitas vezes, não fosse pela difícil arte de delimitar o campo da pesquisa, coletar os dados, contatar os sujeitos, estruturar a análise e dar visibilidade a esse sofrimento por meio de artigos e textos, poder-se-ia 
perder a motivação e o empenho, deixando tudo dentro da conformidade das coisas, caindo em armadilhas de discursos como o citado (Torres, 2015, p. A3; Skaf, 2015). Mas o texto tem um caráter político e um objetivo claro: o de desnaturalizar a exploração da força da força de trabalho e dar voz às vítimas do trabalho.

Recebido em 25/5/2015 - Aprovado em 8/6/2015

\section{Referências bibliográficas}

ALVES, Francisco. Por que morrem os cortadores de cana? Saúde e Sociedade, São Paulo, v. 15, n. 3, p. 90-98, set.-dez. 2006. Disponível em: <http://www.scielo.br/pdf/sausoc/ v15n3/08.pdf>. Acesso em: 23 set. 2012.

ALVES, Giovanni. Trabalho e neodesenvolvimentismo: choque de capitalismo e nova degradação do trabalho no Brasil. Londrina: Praxis Editorial, 2014.

ANTUNES, R. Adeus ao trabalho? Ensaio sobre as metamorfoses e a centralidade do mundo do trabalho. 6. ed. São Paulo: Cortez; Campinas: Unicamp, 1999.

. Produção liofilizada e a precarização estrutural do trabalho. In: LOURENÇO, E. Â. S. et al. O avesso do trabalho II: trabalho precarização e saúde do trabalhador. São Paulo: Expressão Popular, 2010. p. 21-40.

BRASIL. Anuário Estatístico da Previdência Social 2013. Disponível em: <http://www. previdencia.gov.br/wp-content/uploads/2013/05/AEPS_2012.pdf $>$. Acesso em: $1^{\circ}$ maio 2015.

CHESNAIS, François. Como la crisis del 29, o más... Un nuevo contexto mundial. Herramienta, Buenos Aires. Disponível em: <http://www.herramienta.com.ar/revista-impresa/ revista-herramienta-n-39>. Acesso em: 30 dez. 2008.

BARRETO, Margarida; HELOANI, Roberto. Assédio moral e as questões contemporâneas. In: NAVARRO, V.; LOURENÇO, E. Â. S. O avesso do trabalho III: saúde do trabalhador e questões contemporâneas. São Paulo: Outras Expressões, 2013. p. 107-124.

FOLHA DA REGIÃO [on-line]. Vazamento de caldo de cana em usina deixa 15 pessoas feridas. Araçatuba, 15 jun. 2007. Disponível em: <http://www.folhadaregiao.com.br/Materia.php?id=70129>. Acesso em: 10 ago. 2007. 
GAULEJAC, Vicent. Gestão como doença social: ideologia, poder gerencialista e fragmentação social. Aparecida: Ideias e Letras, 2007.

IANNI, Octavio. A classe operária vai ao campo. 2. ed. Cadernos Cebrap, São Paulo, Brasiliense, n. 24, 1977.

LOURENÇO, Edvânia Ângela de Souza. Desemprego, precarização do trabalho e os reversos para a saúde dos trabalhadores. In: SILVA, José Fernando Siqueira; SANT’ANA, Raquel Santos; LOURENÇO, Edvânia Ângela de Souza. Sociabilidade burguesa e Serviço Social. Rio de Janeiro: Lumen Juris, 2013. p. 131-160.

; LACAZ, Francisco Antônio de Castro. Os desafios para a implantação da política de saúde do trabalhador no SUS: o caso da região de Franca/SP. Revista Brasileira de Saúde Ocupacional (RSBO), Brasília, Fundacentro, 2013. Disponível em: <http://www.scielo. br/scielo.php?pid=S0303- 76572013000100008\&script=sci_arttext $>$. Acesso em: 15 set. 2013.

MARX, Karl. O capital: crítica da economia política. 23. ed. Rio de Janeiro: Civilização Brasileira, 2006. Livro I.

ORGANIZAÇÃO INTERNACIONAL DO TRABALHO (OIT). Perfil da acidentalidade no mundo exclui o Brasil das estatísticas atualizadas da OIT. Dados globais, 2010. p. 84-86. Disponível em: <http://www.segurancanotrabalho.eng.br/estatisticas/estacidmundo.pdf>. Acesso em: 18 dez. 2013.

NOVAES, José Roberto. Trabalho e trabalhadores migrantes no Complexo Agroindustrial Canavieiro Paulista. In: ; ALVES, Francisco (Orgs.). Migrantes: trabalho e trabalhadores no complexo agroindustrial canavieiro (os heróis do agronegócio brasileiro). São Carlos: Ed. da Edufscar, 2007. p. 21-54.

RIBEIRO, Herval Pina. Gritos e silêncios: degradação do trabalho e estados de saúde da voz. São Paulo: Vários editores, 2012.

SANT'ANA, Raquel Santos. Trabalho bruto no canavial: questão agrária e Serviço Social. São Paulo: Cortez, 2012.

SELIGMANN-SILVA. Trabalho e desgaste mental: o direito de ser dono de si mesmo. São Paulo: Cortez, 2011.

SKAF, Paulo. Bom para o Brasil, bom para os brasileiros. Folha de S.Paulo, São Paulo, 6 abr. 2015, p. A3, cad. Tendências/Debates.

THOMAZ JR., A. Por trás dos canaviais, os "nós" da cana: a relação capital $x$ trabalho e o movimento sindical dos trabalhadores na agroindústria canavieira paulista: São Paulo: Annablume/Fapesp, 2002. 
TORRES, Miguel. Mais direito. Folha de S.Paulo, São Paulo, $1^{\circ}$ maio 2015, p. A3, cad. Tendências/Debates.

VICENTE, Fernando A. C. Figueiredo. Gestão estratégica da segurança no trabalho na área industrial de uma usina de açúcar, álcool e energia elétrica. Dissertação (Mestrado) — Escola de Economia de São Paulo da Fundação Getúlio Vargas, São Paulo, 2012. Disponível em: <0438/9883/TESE\%20FERNANDO\%20VERS\%C3\%83O\%20FINAL\% 20E\%20OFICIAL.pdf?sequence=1>. Acesso em: 11 jan. 2013. 